\title{
Yaşlıların Aktif Yaşlanma Tecrübeleri: Nitel Bir Çalışma
}

DOI: 10.26466/opus.773745

*

\author{
Birgül Ciçek* - Hande Şahin** - Sibel Erkal *** \\ * Arş.Gör, Hacettepe Ǘniversitesi İ̈BF Aile ve Tüketici Bilimleri Bölümü \\ E-Posta: birgulaydin@hacettepe.edu.tr \\ ORCID: $\quad 0000-0002-3985-6637$ \\ ** Prof. Dr., Kırıkkale Üniversitesi Sağlık Bilimleri Fakültesi Sosyal Hizmet Bölümü \\ E-Posta: hande k1979@yahoo.com \\ ORCID: 0000-0002-0012-0294 \\ *** Prof. Dr., Hacettepe Üniversitesi IİBF Aile ve Tüketici Bilimleri Bölümü \\ E-Posta: serkal@hacettepe.edu.tr \\ ORCID: $\quad$ 0000-0002-8395-9705
}

\section{Öz}

Bu çalışma, Giresun'da yaşayan 65 yaşın üzerinde on beş yaşlı bireyin aktif yaşlanmaya ilişkin deneyimlerini belirlemek amacıyla planlanmış ve yürütülmüştür. Veriler, araştırmacılar tarafından hazırlanan yarı yapılandırlmış görüşme formu ile yüz yüze derinlemesine görüşmeler yapılarak elde edilmiştir. Verilerin analizinde nitel veri analizlerinden betimsel ve içerik analizi yöntemi kullanılmıştır. Araştırmaya göre; katılımcıların 10'u kadın, 5'i erkektir. Yaş ortalaması $70.1 \pm 2.4^{\prime}$ tür. Yaşlıların 7'si gelir seviyesini "orta", 5'i "düşük", 3'ü ise "yüksek" olarak belirtmiştir. Yaşlllar arasında Emekli Sandiğı' 'ndan emekli olanlar ( $n=10), 2$ çocuğu $(n=9)$ ve 2 torunu $(n=8)$ olduğunu belirtenler ile çocuklarıyla birlikte yaşayanlar $(n=6)$ çoğunluğu oluşturmaktadır. Yaşlılardan 10'u tansiyon hastalığının olduğunu, 13'ü sigara kullanmadığın belirtirken; 10 katılımcı günde 3 öğ̈̈n yemek yediğini ifade etmiştir. Ayrıca araştırma sonucunda; yaşlılar arasında komşuluk ilişkilerini "kardeşlik" olarak belirtenlerin, torunları ile ilişkilerinde düzenli olarak görüşenlerin, boş zaman faaliyeti olarak "el işi" yapanların, akıllı telefon kullandığını, Giresun ilinde yerel yönetimin yaşlılara yönelik hizmeti olduğunu belirtenlerin önde geldiği belirlenmiştir. Elde edilen bulgular alan yazindan örneklerle tartışılmış, yaşlılıkta aktif yaşlanma bilincinin yaygınlaştırılması, yaşlının toplumla bütünleşmesi, kaybolan statü ve rollerin yeniden kazanımı, işlevlerin artırılması, boş zamanlarının etkili değerlendirilmesi, gelirlerinin artırılması gibi boyutlarıyla bir bütün olarak değerlendirilerek öneriler sunulmuştur.

Anahtar Kelimeler: Yaşlı, aktif yaşlanma, nitel çalışma. 


\title{
Active Aging Experiences of the Elderly: A Qualitative Study
}

\begin{abstract}
This study was planned to determine the experiences of 15 individuals aged 65 and above living in Giresun regarding active aging. The data were collected using the "individual in-depth interview" method by a semi-structured interview form. Descriptive analysis and content analysis methods, among the qualitative data analyses, were used in the analysis of the data. According to the findings, the participants consisted of 10 women and 5 men. The mean age was $70.1 \pm 2.4$. Among the elderly individuals, those who retired from the Pension Fund ( $n=10)$, those who had 2 children $(n=9)$, those who had 2 grandchildren $(n=8)$ and those who lived with their children $(n=6)$ came to the forefront. While 10 of the elderly individuals stated that they had blood pressure disease, and 13 of them stated that they did not smoke, 10 of them ate 3 meals a day. Also, it has been determined that those who state their neighbourhood relations among the elderly as "fraternity," those who continuous and regular relationship with their grandchildren, those who "do handicraft", and those who use smart phones are the leading ones. The findings were discussed with examples from the literature and suggestions were made.
\end{abstract}

Keywords: Elderly, active aging, qualitative research 


\section{Giriş}

On dokuzuncu yüzyıldan itibaren tıbbı bilginin artışı, sağlık hizmetlerinin gelişmesi, iyileşen sağlık koşulları dolayısıyla doğum-ölüm oranlarının azalması, gelir düzeyinin yükselmesi, teknolojinin insan yaşamına sağladığı kolaylıklar, sağlıklı beslenme, sağlıklı konut gibi sağlığı koruma ve sürdürme konusunda yaşanan bilinçlenme ile gelişen imkanlar yaşam süresinin uzamasinda önemli faktörler olmuştur (Bayrak, 2018; Esendemir, 2016, s.416; GökçeKutsal, 2011). Türkiye'nin 2018-2080 yıllarını kapsayan nüfus projeksiyonunda, ülkemizde doğuşta beklenen yaşam süresinin arttı̆̆ı, ortalama 78,3 yıl olarak belirlendiği ve nüfusumuzun yaşlanmaya devam ettiği belirtilmektedir (Türkiye İstatistik Kurumu [TÜİK], 2018; TÜİK, 2019a). Bu açıdan değerlendirildiğinde; Türkiye' de toplam nüfusun $\% 9,1^{\prime}$ ini 65 yaş ve üzeri nüfus oluşturmaktadır (TÜIK, 2020). Ülkemiz yaşlı nüfus oranlarının 2023'te \%10,2, 2040 'da \%16,3, 2060'ta \%22,6 ve 2080'de \%25,6 olacağı öngörülmektedir (TÜİK, 2018). Diğer bir deyişle 2023 yılında her 10 kişiden 1'inin, 2050 yılında ise her 5 kişiden 1'inin yaşlı olacağı tahmin edilmektedir (T.C. Aile, Çalışma ve Sosyal Hizmetler Bakanlığ1 [AÇSHB], 2018).

Çalışmanın yürütüldüğü Giresun ili ile ilgili olarak yaşlı istatistikleri incelendiğinde; ülkemizdeki yaşlıların \%1,01'inin Giresun'da yaşadığı belirtilmektedir (AÇSHB, 2018, s.253). TÜİK Adrese Dayalı Nüfus Kayıt Sistemi 2018 verilerine göre, Giresun' da 65 yaş ve üzerinde toplam 70495 birey (erkek: 30 440; kadın: 40 055) yaşamakta, yaşlı nüfus da Giresun nüfusunun \%15.04'ünü oluşturmaktadır (AÇSHB, 2019, s.67). Giresun ili, sahip olduğu bu oranla ülkemizde yaşlı nüfus oranının en yüksek olduğu 6. ildir. Ayrıca en yaşlı nüfus olarak tanımlanan 80 ve daha yukarı yaştaki nüfus açısından değerlendirildiğinde ise Türkiye genelinde ikinci il olarak yer almaktadır. Bu verilere göre, Giresun ülkemizin yaşlı kentleri arasında yer almaktadır (AÇSHB, 2018, s.253).

\section{Aktif Yaşlanma ve Yaşlıların Yaşam Kalitesi İlişkisi}

Ülkemizde ve dünyada yaşlı nüfusun giderek artmasıyla günümüzde yaşl1ların yaşam kalitesinin artırılarak, sağlıklı ve başarılı yaşlanmayla sosyal yaşamda daha aktif bir rol almaları amaçlanmaktadır (Danış, 2008, s.95). Bu nedenle; yaşlıların topluma aktif ve üretken bir şekilde katılımlarını sağlayacak 
hizmetler ve politikalar önemli hale gelmektedir (Altuntaş ve Kayıhan, 2012). "İnsanların yaşlandıkça yaşam kalitelerini iyileştirmek amacıyla bu kişilere yönelik sağlık, katılım ve güvenlik konusundaki fırsatların en üst düzeye çıkarılması süreci" olarak Dünya Sağlık Örgütü (2002) tarafından tanımlanan aktif yaşlanma kavramı; bu imkanların tüm bireyleri kapsayacak şekilde sağlanmasını savunmaktadır. Tanımda yer alan aktif kelimesiyle "sosyal, ekonomik, kültürel, manevi ve yurttaşlıkla ilgili konularda süreklilik gösteren bir katılım" ifade edilmektedir (World Health Organization [WHO], 2002, s.12). Aktif yaşlanma kavramını Çetin (2002) ise "yaşam boyunca fiziksel, mental, sosyal iyilik için fırsatları optimum kullanarak yaşam beklentisini, üretkenliği ve yaşam kalitesini artırmak" olarak ifade etmektedir. Dolayısıyla fiziksel, mental, sosyal iyilik ancak sağlıklı bir birey olmakla; sağlıklı bir birey olmak da yeterli ve dengeli beslenme, fiziksel egzersiz yapma, sigaradan uzak bir yaşam, boş zamanları üretken bir biçimde değerlendirme, yeterli ve düzenli uyku ve ev içi kazalardan korunma gibi faktörlerle sağlanabilir (Aslan, 2020).Yaşlılık döneminde bireylerin fiziksel işlevlerinde yavaşlamalarınveya kayıplarınyaşanması nedeniyle (Özyurt vd 2007, s.118); bu dönemde kaliteli yaşlanma diğer bir değişle aktif yaşlanma önem kazanmaktadır. Yaş almayla birlikte ortaya çıkan bu sorunlar yaşlı bireylerin yaşam kalitesi açısından belirleyici olmaktadır (Arpacı, 2015). Dünya Sağlık Örgütü yaşam kalitesini "kendi amaçları, beklentileri, standartları ve ilgilerini göz önüne alarak bireylerin içinde yaşadıkları kültür ve degerler sisteminde kendi konumları ile ilgili algıları" (Kuyken, vd. 1995); Oktik ve Bozyer (2004, s.61) ise "bireylerin içinde bulundugu koşullara baghı olarak deneyimleri sonucu elde ettikleri doyum ve iyilik hali" olarak tanımlamışlardır.

Yaşlıların yasam kalitesinin subjektif ve objektif göstergeleri Oktik ve Bozyer (2004, s.69-82) tarafından ekonomik, sosyal, psikolojik ve sağlık göstergeleri olarak dört başlık altında incelenmektedir.

Yaşla birlikte bireyin, toplumla ve kurumlarla olan ilişkileri zamanla zayıflamakta, yaşlı bireyin sadece kendi ailesi, yaşıyorsa eşi, çocukları ve torunları ile kurabileceği dayanışma ve yardımlaşma temelli kurulan sosyal ilişkiler kalmaktadır. Dolayısıyla yaşlılık döneminde ailenin, bireyin hayatındaki önemi daha da çok artmaktadır (Kalaycıŏglu, 2012). Ülkemizde yaşlıların genellikle çocuklarından biri ile yaşadığı, kendi evlerinde yaşayanların ise yine büyük bir kısmının çocuklarına ya da akrabalarına yakın mesafelerde otur- 
duğu bilinmektedir (İçli, 2008, s.233). Fakat bu her zaman mümkün olmamaktadır. Kuşakların arasına coğrafi mesafeler girmekte, buna bağlı olarak da sosyal ilişkilerde çözülmeler (Schürze ve Wagner, 1995) yaşanmaktadır (Akt. Tufan ve Yazıcı, 2009). Bu durum her ne kadar sosyal ilişkileri olumsuz yönden etkilese de aile büyüklerine yapılan düzenli ziyaretlere ve telefon görüşmelerine engel oluşturmayacağı düşünülmektedir. Yapılan araştırmalar yaşlılık döneminde kuşaklar arası ilişki ve etkileşimlerde sevgi alışverişinin, yeni kurulan aile bağları ve büyükanne/büyükbaba rolü ile yoğunlaştığını göstermektedir (İçli, 2008, s.35) Bilgeliğin en üst seviyesine ulaşan yaşlı bireyin yaşamla birlikte edindiği deneyimlerini çocukları ve torunlarıyla paylaşması ile kültürel aktarım gerçekleşerek, torunların toplumun kültürünü tan1ması sağlanırken, gelenek ve görenekler de korunarak devam ettirilmektedir. Yaşanan karşılıklı etkileşim, hem yeni nesillerin hem de yaşlıların yaşamına olumlu katkılar sağlamaktadır. Yaşlıların aile, arkadaş, akraba ve komşularla olan sosyal ilişki ağının genişliği hayatlarına anlam katmaktadır (Demirbaş, 2018). Ailenin olmadığı ya da fiziki olarak uzak olduğu durumlarda arkadaşlar ve komşular ilgi elde etme, bilgi ve becerileri paylaşma, öneri getirme, yardım etme, iş birliği sağlama ve ihtiyaçların giderilmesinde önemli destek mekanizmaları olmaktadır (Durak, 2013; Kılavuz, 2005; Şener, Öztop, Güven ve Doğan, 2007). Günümüzde sosyal yaşamın sürdürülmesinde ve sosyal problemlerin çözümünde önemli rol oynayan yaşl1lık döneminde teknolojik ürünlerin etkin kullanımı da yaşlıların sosyal uyum ve yaşam kalitelerini artıran faktörler arasında sayılmaktadır (Özkan ve Purutçuoğlu, 2010, s.38). Boş zaman faaliyetleri de bireylerin yaş almayla birlikte yaşadıkları değişimlere uyum sağlamasına yardım eden faktörlerden olmakla birlikte (Raymore ve Scott, 1998; West, Delisle, Simard ve Drouin, 1996); yaşlıların yaşam kalitesini yükselten etkenlerdendir (Allison ve Smith, 1990).

Yaşlıların yaşam kalitelerini artırmaya yönelik hizmetleri olan kurum/kuruluşlar arasında yerel yönetimler de bulunmaktadır. Türkiye'de Yaşlanma ve Ulusal Eylem Planı Uygulama Programı'nda (2013) yerel yönetimlerin yaşlılara gida, yakacak yardımı yaptıkları ve ev temizliği konusunda hizmet sundukları, ekonomik ve kültürel olarak gelişmiş belediyelerin ise, aşevinden evlere yemek dağıtımı, ambulansla evden sağlık hizmeti verdiği açıkça belirtilmiştir (AÇSHB, 2013). Yerel yönetimler tarafından verilen bu hizmetler aynı zamanda bireylerin yerinde yaşlanmalarını kolaylaştırma noktasında da önem arz etmektedir. Yaşlılıkta güvenlik ve korunmayı sağlayan, akraba ve 
arkadaşlık ilişkileri ile bazı boş zaman faaliyetlerinin gerçekleştirilmesine olanak sağlayan ev, fiziksel sağlığın ve psikolojik refahın sürdürülmesine de katkıda bulunur (Gönen ve Özmete, 2005). Nitekim konuyla ilgili yapılan çalışmalarda; yaşlıların huzurevi yerine kendi yaşadıkları evde, bulundukları ortamı terk etmeden bakım görme fikrine daha ılımlı yaklaştıkları vurgulanmıştır (Akgül, 2018; Çiçek, Şahin ve Erkal, 2020; Şentürk ve Kurtkapan, 2017).

Ayrıca yaşlıların gelir düzeyi de yaşam kalitesinin önemli belirleyicilerindendir. Gelirin, insan yaşamı boyunca farklı dönemlere göre değişim gösterdiği bilinmekle birlikte; yaşlılar yaşlılık döneminde emeklilik sonrası gelirde azalma, yaşlıların istihdam edilmesindeki güçlükler, artan sağlık harcamaları, hayat pahalılığı gibi nedenlerle ekonomik sıkıntılar ve yoksullukla baş etmek zorunda kalmaktadır (Danış, 2020). Ülkemizde yaşlı profili düşünüldüğünde; memur, işçi ve esnaf emeklisi (Emekli Sandığı, SSK ve Bağkur sosyal güvencesine sahip fakat 2012 yılından itibaren SGK'lı (Sosyal Güvenlik Kurumu) oldukları söylenebilir. Emeklilik geliri olan yaşlılar ile hiçbir geliri olmayıp 2022 sayılı 65 Yaşını Doldurmuş Muhtaç, Güçsüz ve Kimsesiz Türk Vatandaşlarına Aylık Bağlanması Hakkında Kanun kapsamında aylık geliri olan yaşlıların genel olarak düşük geliri olduğu görülmektedir.

Bu çalışma, Giresun ilinde yaşayan 65 yaş ve üzerinde olan on beş katılımcının; komşuları ve torunları ile ilişkileri, boş zamanlarını değerlendirme durumunu, teknoloji kullanımını, yerel yönetimin yaşlılara ilişkin hizmetlerini kullanma durumunu, kurum bakım hizmeti almaya yönelik düşünceleri ve mevcut gelirine yönelik düşünceleri açısından aktif yaşlanmaya ilişkin deneyimlerini nitel bir çalışma şeklinde incelemek amacıyla planlanmış ve yürütülmüştür.

\section{Yöntem}

Araştırmada nitel araştırma desenlerinden olgu bilim (fenomenoloji/phenomenology) yaklaşımı kullanılmıştır. Bu yaklaşım; bireylerin bir kavrama ilişkin algılarını, betimlemelerini, hislerini ve görüşlerini ortaya çıarmayı amaçlamaktadır (Patton, 2014). Fenomenolojik çalışmalarda, bireylerin kendi yaşamlarındaki hayat tecrübeleri, günlük deneyimleri esas alınmaktadır (Ersoy, 2016; Merriam, 2013). Olgubilim olarak da adlandırılan fenomenoloji “Gerçek nedir?" sorusuna cevap arayan bir yöntemdir. Fenomenoloji yaklaşımın te- 
melini bireysel tecrübeler oluşturmaktadır. Bu yaklaşımda araştırmacı katılımcının kişisel (öznel) tecrübeleri ile ilgilenmekte, bireyin algılamaları ve olaylara yükledikleri anlamları incelemektedir. Fenomenoloji tanımlayıcı bir araştırmadır. Bu bağlamda genelleme yapmak değil, olguları tanımlamak önemlidir (Akturan ve Esen, 2008).

\section{Veri Toplama Yöntemi ve Aracı}

Giresun'da yaşayan 65 yaş ve üzeri on beş bireyin aktif yaşlanmaya ilişkin deneyimlerini belirlemek amacıyla planlanan bu çalışma için veri toplama aracı olarak yarı yapılandırılmış görüşme formu hazırlanmıştır. Form hazırlanmadan önce alan yazın taranmıştır. Kapsam ve görünüş geçerliği açısından alanında uzman iki öğretim üyesinin görüşü alınarak forma son şekli verilmiştir. Görüşme formunda yaşlıların sosyo demografik özelliklerine (cinsiyet, yaş, sosyal güvenceye sahip olma durumu, birlikte yaşadığ 1 kişiler, çocuk sayısı, torun sayısı), sağlık durumuna (sağlık sorunu olup olmadığı, sigara kullanma durumu ve günlük öğün sayısı) ilişkin sorular ile gündelik hayat pratiklerini ortaya çıkarmak amacıyla komşular ve torunlarla ilişkiler, boş zaman faaliyetleri, teknoloji kullanımı, yerel yönetimin yaşlılara ilişkin hizmetlerini kullanma durumu, kurum bakım hizmeti almaya yönelik düşünceler ve geliri yeterli bulma durumuna ilişkin sorular bulunmaktadır.

Veriler Giresun il merkezinde yaşayan kar topu tekniğiyle belirlenen on beş 65 yaş ve üzeri bireyle yaşlılarm evinde "bireysel derinlemesine görüşme" yöntemi kullanılarak elde edilmiştir. Neuman (2003) kartopu tekniğini, araştırmacının bir vaka ya da bireyle başlayarak, o vaka ya da bireyden aldığı bilgiyle başka vaka ve bireylere ulaşması olarak ifade etmiştir. Bu süreç istenilen yeterli örneklem sayısına ulaşana kadar tekrarlanmaktadır. Görüşmeye başlamadan önce katılımcılara araştırmanın amacı anlatılarak, araştırmanın bilimsel amaçlı olarak yürütüldüğü, kimlik bilgilerinin gizli kalacağı, istedikleri zaman araştırmadan çekilebilecekleri ve ses kaydının yapılmak istendiği gibi etik konularda bilgi verilmiştir. Araştırmaya katılmayı kabul eden yaşlılardan gönüllü olarak katıldıklarını belirten sözlü ve yazılı onamları alınmıştır. Görüşmeler sadece katılımcının ve veri toplayan araştırmacının yalnız olduğu bir odada ses kayıt cihazı kullanılarak kayıt altına alınmıştır. Araştırmacı tarafından görüşmenin engellenmemesi için görüşme yapılan ortamın sessiz, sakin olması ve görüşmenin bölünmemesi sağlanmıştır. Her bir yaşlı 
ile bir defa görüşme yapılmıs, görüşme süresi ortalama 30-50 dakika kadar sürmüştür. Ses kayıt cihazına kaydedilen görüşmeler daha sonra bilgisayar ortamına aktarılarak değerlendirme aşamasına geçilmiştir. Araştırmaya başlamadan önce Hacettepe Üniversitesi Etik Komisyonu tarafından 23 Haziran 2020 tarih ve 35853172 sayılı karar) izin alınmıştır. Ayrıca, araştırmacılar ve örneklem grubunu oluşturan bireyler arasında herhangi bir çıkar çatışması bulunmamaktadır.

\section{Verilerin Değerlendirilmesi ve Analizi}

Görüşme formundaki sorulara katılımcıların verdikleri cevaplar geçerlik için araştırmacılar tarafından yorum eklemeden yalın halleri ile yazıya aktarılmıştır. Erkek katımclar E1, E2, E3, E4 ve E5, kadın katımcılar ise K1.............K10 olarak ifade edilmiştir. Elde edilen görüşler ayrı ayrı kodlanmış, ortak ifadeler gruplandırarak tasnif edilmiş ve kategoriler oluşturulmuştur. Oluşturulan kategoriler ilgili alanda uzman kişilerin görüşlerine sunulmuş, tekrar gözden geçirilerek son hali verilmiştir. Yaşlıların sosyo-demografik ve sağlık durumuna ilişkin bilgileri için tablolar oluşturulmuş, konuya ilişkin sorulara verilen cevaplar ise doğrudan alıntılar şeklinde verilmiştir.

\section{Bulgular ve Tartışma}

\section{Katılımcıların SosyoDemografik Özelliklerine İlişkin Bilgileri}

Çalışma Giresun il merkezinde yaşayan 15 yaşlı bireyin katılımıyla gerçekleştirilmiş̧ir. Katılımcılar, 10 kadın ve 5 erkekten oluşmaktadır. Yaşlıların yaş ortalaması 70.1 $\pm 2.4^{\prime}$ tür. Yaşlıların 7'si gelir seviyesini “orta", 5'i “düşüü", 3'ü ise "yüksek" olarak belirtmiştir. Yaşlılar arasında Emekli Sandığı'ndan emekli olanlar $(n=10), 2$ çocuğu $(n=9)$ ve 2 torunu $(n=8)$ olduğunu belirtenler ile çocuklarıyla birlikte yaşayanlar $(\mathrm{n}=6)$ sayıca fazladır (Tablo 1 ). 
Tablo 1. Katılımcılarnn sosyo-demografik özelliklerine göre dağılımı

\begin{tabular}{|c|c|c|}
\hline Değişkenler & Grup & $\mathbf{n}$ \\
\hline \multirow{2}{*}{ Cinsiyet } & Kadın & 10 \\
\hline & Erkek & 5 \\
\hline \multirow{3}{*}{ Gelir Düzeyi } & Düşük & 5 \\
\hline & Orta & 7 \\
\hline & Yüksek & 3 \\
\hline \multirow{3}{*}{ Sosyal Güvence } & SSK & 3 \\
\hline & Emekli Sandiğı & 10 \\
\hline & Bağkur & 2 \\
\hline \multirow{3}{*}{ Çocuk Sayısı } & 1 & 2 \\
\hline & 2 & 9 \\
\hline & 3 & 4 \\
\hline \multirow{4}{*}{ Torun Sayısı } & 1 & 2 \\
\hline & 2 & 8 \\
\hline & 3 & 3 \\
\hline & 4 & 2 \\
\hline \multirow{4}{*}{ Birlikte Yaşanılan Kişiler } & Yalnız & 2 \\
\hline & Eşi ile & 4 \\
\hline & Eşi ve çocukları ile & 3 \\
\hline & Çocukları ile & 6 \\
\hline Toplam & & 15 \\
\hline Yaş & $\dot{\mathrm{X}}=70.1 \pm 2.4$ & \\
\hline
\end{tabular}

\section{Katılımcılarnn Sağlık Durumlarnna İlişkin Bilgileri}

Çalışmaya katılan bireylerin sağlık durumlarına ilişkin bilgiler Tablo 2.de verilmiştir. Yaşlılardan 10'u tansiyon hastası olduğunu, yine aynı sayıda yaşlı günde 3 öğün yemek yediğini; 13'ü sigara kullanmadığını belirtmiştir.

Tablo 2. Katılımcıların sağlık durumlarına ilişkin bilgilerine göre dağılımı

\begin{tabular}{lll}
\hline Değişkenler & Grup & $\mathbf{n}$ \\
\hline \multirow{4}{*}{ Sağlık Sorunu } & Yok & 2 \\
\cline { 2 - 3 } & Tansiyon & 10 \\
\cline { 2 - 3 } & Şeker & 2 \\
\cline { 2 - 3 } & Tansiyon-Şeker & 1 \\
\hline \multirow{2}{*}{ Sigara Kullanma Durumu } & Evet & 2 \\
\cline { 2 - 3 } & Hayır & 13 \\
\hline \multirow{2}{*}{ Günlük Öğün Sayısı } & 2 & 2 \\
\cline { 2 - 3 } & 3 & 10 \\
\hline Toplam & 4 & 15 \\
\hline
\end{tabular}




\section{Katılımcılarn Komşuluk İlişkilerine Yönelik Düşünceleri}

Araştırmaya katılan yaşlılara ilk olarak komşuluk ilişkilerine yönelik düşüncelerini belirlemek amacıyla "komşuluk denilince aklınıza ne geliyor?" sorusu yöneltilmiştir. Verilen yanıtlar, "Kardeşlik", "Yardımlaşma" ve "Birlik ve beraberlik" olmak üzere 3 kategoriye ayrılmıştır.

Katılımcıların 8'i komşuluk ilişkilerini "kardeşlik", 4'ü "yardımlaşma", 3 'ü ise "birlik ve beraberlik" olarak tanımlamıştır.

Komşuluk kavramını "kardeşlik" olarak tanımlayan yaşlılar uzun yıllar bir arada olduklarını, bu nedenle birbirlerini çok iyi tanıdıklarını, güzel vakit geçirdiklerini belirtirken; birlikte geçirdikleri zamana vurgu yapan yaşlılar komşuluğu aşağıdaki gibi ifade etmektedir:

- "30 yıldır aynı mahallede oturuyoruz. Evlendiğimde bu mahalleye gelin gelmiştim. Kardeşlerimden çok komşularm ile vakit geçirir oldum. Artık birbirimizin her şeyini bilir durumdayız. Daha çok görüşı̈̈̆g̈üm 3-5 komşum var, kardeş gibi olduk. Her sabah birbirimize kahveye gider geliriz. Akşamları da görüşürüz tabi."(K1)

- "Komşularım değil onlar kardeşlerim benim. 40 yıl oldu neredeyse. Çok iyi vakit geçiyorum onlarla. Yoksa zaman hiç geçmek bilmiyor." (K10)

Eskiden herkesin birbirini tanıdığına vurgu yapan bir yaşlı ise;

- "Mahallede herkes birbirini tanır. Daha eskiden çarşıya indik mi herkes birbirini tanırdr. Şimdi daha yeni nesiller geldi. Eskiler harici tanımıyorum diğerlerini. Apartman komşularım pek iyidir. Aynı kardeş gibiyiz. Birlikte örgü örer sohbetler ederiz." (K5) şeklinde düşüncelerini paylaşmıştır.

Komşuluk kavramını "yardımlaşma" olarak tanımlayan yaşlılar, zor günlerde dayanışma içinde olduklarını ve birbirlerinin ihtiyaçlarını karşıladıklarını ifade etmişlerdir:

- “Komşuluk demek zor günlerinde birbirine yardima olmak demek. Gençliğimde kimin bir ihtiyacı olsa hemen koşup yetişirdim. Yaşlanınca da sağ olsun gençler yardımcı hep." (E3)

- "Komşularımdan birine misafir gelecek ise toplanır yardım ederiz. Aynı şekilde onlar da bana yardim eder. Herkes birbirini tanyor zaten mahallede."(K2) 
Komşuluğu "birlik ve beraberlik" olarak açıklayan bir yaşlı ise, komşularıyla iyi anlaşmaları nedeniyle ortak karar almada kolaylık yaşadıklarını şu şekilde ifade etmektedir:

- "Komşuluk denilince aklıma birlik ve beraberlik geliyor. Çokşükür komşularımla iyi anlaşıyorum. Apartman ile ilgili bir karar alınacaksa kimse karşı çıkmıyor. Hep beraber iyi olan ne ise onu yapmaya çalışıyoruz." (E1)

Bu sonuçlar, çalışmaya katılan tüm yaşlıların komşuları ile iyi ilişkiler geliştirdiği ve komşuları ile ilgili olumlu düşünceler içinde olduğunu göstermektedir. Çalışmanın bulgularına paralel olarak Özkul, Kalaycı ve Atasoy'un (2019) çalışmasında katılımcıların komşularıyla iletişimlerinden memnun oldukları belirtilmiştir. Özkan'ın (2017) yaşlıların mekan aidiyeti üzerine yaptığı çalışmasında, yaşlı bireylerin özgürlük kavramına ilişkin algılarında komşularıyla olan iyi ilişkilerinin yer aldığı da görülmektedir.

\section{Katılımcılarn Torunlan ile İlişkilerini Değerlendirmeye Yönelik Düşünceleri}

Katılımcılara torunları ile ilişkilerini değerlendirmeleri amacıyla ilişkilerinin nasıl olduğu, düzenli olarak arayıp ziyarette bulunup bulunmadıkları sorulmuş, verilen yanıtlar düzenli ve düzensiz ilişkiler olmak üzere iki kategoriye ayrılmıştır.

Çalışmaya katılan yaşlıların 12'si torunları ile devamlı ve düzenli bir ilişkilerinin olduğunu, birbirlerini sık sik arayıp görüştüklerini belirtirken, 3 'ü aralarındaki ilişkinin kopuk olduğunu belirtmiştir. Yaşlı bireylerin çocuklarının ve torunlarının yaşamlarına sağlamış oldukları katkı aktif yaşlanmayı da destekleyen bir süreçtir. Bu süreçte yaşlllar, çocuklarının veya torunlarının yaşamlarına işlevsel ya da duygusal katkı sağlayarak kendi yaşamlarını da daha başarılı ve aktif bir şekilde sürdürebilmektedir. Ayrıca bu durum yaşl1lıkta görülen "yalnızlı" ve "kendini işe yarar hissetmeme" gibi önemli sorunlar için de çözüm olabilmektedir (Özmete, 2014, s.224).

Torunlarıyladevamlı ve düzenli bir ilişkilerinin olduğunu, birbirlerini sık sık arayıp görüştüklerini belirten yaşlılar:

- "Torunlarm evlatlarmdan öte. İkisi de üniversiteye gidiyor. Biri bu sene bitirecek. Yaz tatillerinde hep gelirler yanmma. Birkaç hafta benimle kahrlar."(K3) 
- “Allah bu günümüzü aratmasm. Kimsenin gözünü yollarda, kulağın telefonda brrakmasın. Torunlarm oğullarımdan çok arayıp sorarlar. Başka şehirde yaşıyorlar ama senede iki kere birlikteyiz. Canları să̆ olsun da uzaklarda olsunlar."(K7)

Torunuyla aynı şehirde yaşayan bir yaşlı ise ilişkilerini:

- "Kızım bana çok düşkündür. Öyle olunca torunlarım da düş̌ün oldu. Aynı şehirde yaşadığımız için Pazar günleri mutlaka bir araya gelir, pide yeriz. Bizim burada Pazar günleri firnnlar pide yapar. Gelenek oldu artık. Şehir dışında değillerse mutlaka birlikteyiz."(E4) şeklinde ifade etmiştir.

Şentürk ve Ceylan'ın (2015) çalışmasında çocuğu olan yaşlı bireylerin tamamına yakınının yaşadığı yerde ulaşabilecekleri en az bir çocuğunun olduğu, çocukları ve torunları tarafından haftada en az bir kez ziyaret edildiği belirlenmiştir. Yaşlıların çocuklarıyla aynı şehirde yaşamaları birlikte zaman geçirmelerine olanak sağlayarak, nesiller arası ilişkiyi güçlendirdiği düşünülmektedir.

Torunları ile düzenli ilişkileri olmayan yaşlılar ise torunlarının yurtdışında ya da şehir dışında yaşadıklarından çok sık görüşemediklerini dolayısıyla ilişkilerinin kopuk olduğunu ifade etmişlerdir:

- "Çocuklarım da torunlarm da yurt dışında. Herkesin ayrı bir hayatı var. Geçim derdi var. Bazen hiç gelemezler buraya. Bazen çocuklar gelir torunlar kalir. Ya da torunlar başka yerde tatil ister. Çocuklar arar sorar şimdi Allah'ı var. Ama torunlar genç işte. Biz onlara uyum sağlayamıyoruz, onlar da bize."(E2)

- "Torunlar başka şehirlerde hep. Çok az görürüm onlarn. Bayramdan bayrama ararlar. Sağglklı olsunlar da aramasinlar." (E5)

Çocukları ile farklı şehirlerde yaşayan yaşlıların torunlarını görme durumu coğrafi uzaklık-yakınlıktan etkilendiği, genellikle tatillerde ve bayram ziyaretlerinde bir araya gelindiği belirlenmiştir. Özmete'nin (2017) kuşaklararası dayanışmanın değerlendirildiği çalışmasında da benzer bulgulara rastlanılmiştır. 


\section{Katılımcılarnn Boş Zaman Faaliyetlerine İlişkin Bilgileri}

Çalışmaya katılan yaşlılara boş zamanlarını nasıl değerlendirdiklerine ilişkin bilgi edinmek amacıyla "boş zamanlarınızı nasıl değerlendiriyorsunuz?" sorusu yöneltilmiştir.

Katılımcların 8'i boş zamanlarında el işi yaptığını; 3'ü gezdiğini, 2'si ibadet ettiğini, 2'si ise TV izlediğini belirtmiştir.

Çalışmaya katılan 10 yaşlı bireyin kadın olduğu göz önüne alındığında; boş zamanlarını el işi yaparak değerlendirmeleri beklenen bir sonuçtur. Kadın katılımcılar el işi yapma nedenlerini aşağıdaki gibi ifade etmişlerdir:

- "El işine meraklıyım. Hala elimden geldikçe bir şeyler örmeye çalışırm. Bebek yelekleri, battaniye. Mahallede bir şey moda olunca tüm komşular ondan örmeye başları.."(K4)

- “Ev işlerim bittikten sonra el işi yapmayı çok severim. Ev yün dolu. Yardım ve hayır olsun diye yaparm çoğunu zaten."(K9)

- "Elimde oyalandığım örgülerim var. Zaman nasıl geçiyor anlamıyorum hiç. Zaten onlar olmasa kendini dinlemeye başlar herhalde insan."(K6)

Yaşlılar hava güzelse parklarda oturmayı, arkadaşlarıyla buluşmayı tercih etmeleri nedeniyle boş zamanlarını gezerek değerlendirmektedir:

- "Kahvaltımı yaptıktan sonra dışarı çıkarım. Dolaşırım dışarda. Hava güzelse parkta otururum. Alnacaklar varsa eve gelirken alırm onlar da."(E1)

- "Evde oturamam hiç. Allah sağlık versin. Hava iyiyse çıkarım dışarıya. İnerim sahile. Otururum parkta. Geleni geçeni izlerim." (E3)

- "Kahvaltıdan sonra evi derler toplarm. Sonra dışarıya çıkarm. Arkadaşlarla bir şeyler yaparı. Bazen dışarda buluşuruz, bazen evlerde" (K7)

Boş zamanlarını ibadet ederek geçiren yaşlıların ikisi de erkektir. Bu durumu aşağıdaki gibi ifade etmişlerdir:

- "Camiye gidip geliyorum sürekli. Arkadaşlarım da görüyorum orada. Konuşuyoruz, sohbet ediyoruz."(E2)

- "Yaşlanınca insan kendini ibadete veriyor. Namazımı kllarım, tesbihimi çekerim. Boş kaldıkça Kuran da okurum." (E4) 
Daha çok evde vakit geçiren ve TV izleyerek boş zamanlarını değerlendirdiğini belirten iki yaşlı bireyin biri kadın biri erkektir. Katılımclar vakit geçirmenin yanı sıra haberleri, dizileri izlemek amacıyla TV izlediklerini şu şekilde ifade etmişlerdir:

- "Vakit geçirmek için televizyon izliyorum. Genelde haber programlarna bakarm. Bir de TRT'de Seksenler diye bir dizi var. Akşamlar da haber öncesi onu izlerim. Eski Zamanları hatırlatır bana."(E5)

- "Her gün düzenli izlediğim programlar var. Gündüz onlarn izliyorum, akşamları da dizilerim var onlarn izliyorum. Böyle olunca zaman nasıl geçiyor anlamıyorum hiç." (K2)

Caldwell, Smith ve Weissenger (1992) fiziksel, mental ve sosyal sağllğın aktif boş zaman faaliyetlerine katılım ile yakından ilişkili olduğunu bildirirken; Stav, Hallenen, Lane ve Arbesman (2012) boş zaman faaliyetleri ile sosyal ve dini faaliyetlerin, yaşlıların sağlığını ve yaşam kalitesini olumlu açıdan etkilediğini belirtmiştir. Dini faaliyetler aracılığıyla yaşlı bireyler, yeni arkadaşlık ilişkileri kurma ya da arkadaşlık ilişkilerini geliştirme açısından imkanlara sahip olmaktadır (Durak, 2013; Kılavuz, 2005). Nitekim çalışmanın bulgularında da camiye giden yaşlı bireyin arkadaşlarıyla görüştüğü, sohbet ettiği belirlenmiştir. Boş zamanlarını ibadet ederek geçirdiğini belirten diğer yaşlı birey ise yaşlanmayla ibadet etmeye düşkünlüğünün arttğını belirtmektedir. Alan yazın incelendiğinde; Yüksel, Dinçer, Büyükköse ve Lale'nin (2014) İstanbul'da (Başakşehir) yaşayan 17 yaşlı bireyin boş zamanlarını değerlendirmelerini belirlemek amacıyla yürüttükleri çalışmada; bireylerin yaşlılıkla birlikte dini faaliyetlere eğilim gösterdiği belirtilmekle birlikte; yaşlıların boş vakit etkinliklerini değerlendirme ile cinsiyet, medeni durum, çocuk sayısı, çocuklarla görüşme sıklı̆̆ı arasında bir ilişki olmadığı, yaşlıların boş zamanlarını dini ve yardım faaliyetlerinde bulunarak ve kitap okuyarak değerlendirdiklerini saptamışlardır. Özdemir' in (2017) çalışmasında da benzer bulgulara rastlanılmıştır. Yaşlılar ibadet ederek, arkadaşlarıyla sohbet ederek, parka giderek ve televizyon izleyerek boş vakitlerini değerlendirdiği ifade edilmiştir. Çubuk (2019) 60 yaş üstü bireylerin katıldıkları boş zaman aktivite türleriyle yaşam doyumu ve arasındaki ilişkiyi incelediği çalışmasında, yaşlı bireylerin en çok ev merkezli sosyal etkinlikler (arkadaş ziyaretleri, aile ile vakit geçirme vb.), kültürel ve eğlence içerikli etkinlikler (tv izleme, sinemaya gitme vb.), 
hobiler ve iç mekan etkinlikleri (kitap okuma, resim yapma vb.), açık alan etkinlikleri (yürüyüss, bisiklete binme vb.), fiziksel etkinlikler (spor ve egzersiz), gönüllülük ve sosyal sorumluluk etkinliklerine katılım gösterdiği belirlenmiştir. Dupuis ve Smale (1995) ise yaşlıların yüzme, hobi edinme, el sanatları ile uğraşma, arkadaş ziyaretlerinde bulunmalarının psikolojik refahlarını artırdığı, depresyon riskini azalttığı sonucuna varmıştır. Dolayısıyla zamanının büyük bir kısmını evde geçiren yaşı bireyler için edindikleri uğraşlar ve hobiler onları bu olumsuz etkilerden kurtarabilir. Yaşlıların ruhsal ve sosyal yönden kendini iyi hissetmesine katkı sağlayacak hobiler ve iç mekân etkinlikleri, yaşlılığın olumsuz etkilerini ortaya çıkmasını önlemede de geciktirici bir rol oynayabilir (Aydın ve Tütüncü, 2017).

Katılımclların verdikleri cevaplar düşünüldügünde, yaşlıların boş zaman değerlendirmesi konusu geliştirilmesi gereken bir alan olarak düşünülmektedir. Çünkü sağlıklı yaşlanma, ancak üretken olmak, ilişkiler kurmak ve uğraşlar edinmekle sağlanabilir (Sarıŏlu ve Ertuğrul, 2001). Bu açıdan düşünüldügüunde el işleri yapma, gezme, ibadet etme ve televizyon izlemenin yanı sıra yaşllların fiziksel ve psiko-sosyal yönden yaşam kalitelerini artırmaya yönelik boş zaman faaliyetlerinden olan fiziksel faaliyetlere ve kültürel faaliyetlere katılım, bahçe işleriyle uğraşma gibi faaliyetleri gerçekleştirmeleri konusunda desteklenmeleri gerektiği söylenebilir.

\section{Katılımcıların Teknoloji Kullanımına İlişkin Bilgileri}

Bireylerin teknoloji kullanımına ilişkin bilgi edinmek amacıyla katılımcılara "akıllı telefon ya da bilgisayar kullanıyor musunuz? şeklinde bir soru yöneltilmiştir. Verilen cevaplar 3 farklı kategoriye ayrılmıştır.

Yaşlıların 8'i akıllı telefon, 2'si bilgisayar kullanmaktadır. Yaşlılardan 5'i ise akıllı telefon ya da bilgisayar kullanmayarak teknoloji ile arasının iyi olmadığını belirtmiştir.

Coğrafik uzaklık nedeniyle yaşlılar daha çok akıllı telefon aracılığıyla görüntülü konuşarak iletişim kurmayı tercih ettiklerini, diğer özelliklerini bilmediklerini belirtmişlerdir:

- “Oğlum almış getirmiş bu telefonu. Görüntülü konuşabilelim diye. Uzakta olunca haber almak istiyor tabi sık sık. Ben de açmayı kapamayı, mesaj atmayı biliyorum. Öyle internet falan bilmem ben. Telefon konuşmak için kullanlır."(K3) 
- “Çocuklarım yurt dışında olduğu için görüntülü konuşuyoruz. O yüzden de son model telefon olmasi gerekiyor. Memnunum telefonumdan. Başka özellikleri de varmış ama bilemiyorum ben." (E2)

Bilgisayar kullanan bir yaşlı ise:

- "Küçük bilgisayarm var. Gazetelere bakayım diye almışlar bana. Zaten başka da bişeycik için kullanmıyorum." (E3) şeklinde ifade etmiştir.

Teknoloji ile arası iyi olmadığını belirten yaşlılar ihtiyaç olduğunda ev telefonu kullandıklarını, yeni teknolojilerin çabuk bozulabildiğini belirtmişlerdir:

- $\quad$ "Komşularımla çok vakit geçiyorum. Cep telefonu kullanmıyorum. Ev telefonu var. İhtiyaç olduğunda onu kullaniyorum. Eski şeyler daha să̆lam ve dayanıkl. Yeni alet aldığın zaman hemen bozuluyor. O yüzden ben de hep alışkanlıklarımdan dolayı teknolojiyi takip etmiyorum."(K10)

- "Yillardır ayni mahallede, ayni evde otuyorum. Eski zaman insaniyız biz. Öyle eşyamız bozuldu hop at, yenisi al olmaz. Tamir ettirip kullanrım. Telefonum var küçük bir tane. Kullanıyor musun desen yok derim. Bazen açmayı bile unutuyorum. Arayan soran evden arar nasıl olsa."(K1)

Katılımcıların bu soruya verdikleri cevaplar ve teknoloji kullanımına ilişkin görüşleri ele alındığında; yaşlıların aile bireyleri, komşuları, arkadaşları ile görüşme sıklığı, aralarındaki coğrafi mesafenin kullandıkları iletişim aracını etkilediği bulunmuştur. Yaşlıların bir kısmı aile bireyleri ile aralarındaki uzaklık nedeniyle akıllı telefon kullandığını belirtirken; bir kısmı da komşularıyla yakın ilişki içinde olduklarından ve teknolojik araçlara ilişkin tutumlarından dolayı teknolojiyle aralarının iyi olmadığını ifade etmiş̧lerdir. Yaşlıların teknolojik yenilikleri kabullenmelerinde Zimmer ve Chappell (1999) yaşlıların cinsiyet, yaş, eğitim ve gelir düzeyi, ev sahibi olma, yaşadıkları yer gibi sosyo demografik özellikleri, önceki tecrübeleri ve ürüne yönelik duyduğu ihtiyaçları; Wang, Rau ve Salvendy (2011) ise tatmin ihtiyacı, desteğin mevcudiyeti, algılanan kullanılabilirlik ve sosyal kabul görmenin etkili faktörler olduğunu belirtmişlerdir. Çalışmanın sonuçlarına benzer şekilde Baran-Görgün, Kurt-Koçak, Tekeli-Serdar' ın (2017) 60-74 yaş arası yaşlı bireylerin yeni iletişim teknolojilerini kullanım becerileri, kullanım amaçları, araçları 
ve sıklıklarını belirledikleri çalışmasında; yaşlı bireylerin bilgisayar ve internet kullanmayı bilmemesi ve gerek duymaması gibi nedenlerle teknoloji kullanımından uzak durdukları bildirilmiştir.

Türkiye'de yaşlıların teknoloji kullanımının belirlendiği çalışmaların başında gelen Hane halkı Bilişim Teknolojileri Kullanım Araştırması'na göre, 65-74 yaş aralığındaki bireylerin \%8,5' inin bilgisayar, \%19,8' inin internet kullandığ 1 ; bilgisayar ve internet kullanan erkeklerin oranının (\%11,5 ve \%25,3) kadınlara $(\% 5,9$ ve \%15,0) göre daha yüksek olduğu belirlenmiştir (TÜIKK, 2020). Bu çalışmanın aksine Baran-Görgün, Kurt-Koçak, Tekeli-Serdar'ın (2017) çalışmasında; cinsiyet ile yeni iletişim teknolojilerinin kullanımı arasinda fark bulunmamıştır. Yine aynı çalışmada yaşlıların \%91,4'ü cep telefonu/akıllı telefon, \%21,2'si dizüstü bilgisayar/notebook kullandığı belirlenmiştir. Yeni iletişim teknolojilerini kullanmadığını belirtenler ise erkeklerin \%21,7'sini, kadınların \%17,4'ünü oluşturduğu sonucuna varılmıştır. Yaşlıların en çok haber sitelerini ziyaret etme $(\% 8,4)$ amaciyla internet kullandıklarını belirtilmiştir. Paul ve Stegbauer (2005) tarafından Almanya'daki genç ve yaşlılara yönelik yapılan çalışmada, Almanya'da yaşayan yaşlılar, haberleri ve belli bilgileri takip etmeleri nedeniyle interneti kullandıklarını ifade etmişlerdir. Sungur ve Hazer (2019) Adana'da yaşayan 60 yaş üstü bireylerin \%71,4' ünün cep telefonu ve akıllı telefon kullandığını, \%53,7'sinin ise bilgisayar ve interneti duyduklarını ancak hiç kullanmadıklarını belirtmişlerdir.

\section{Katılımcılarn Yerel Yönetimin Yaşlılara Yönelik Hizmetlerini Kullanma Durumuna İlişkin Bilgileri}

Çalışmaya katılan yaşlılara "ilinizdeki yerel yönetimin yaşlılara yönelik hizmetleri var $\mathrm{m}$ ? Bu hizmetlerden yararlanıyor musunuz?" soruları yöneltilmiş olup, cevaplar verilen hizmetleri bilenler ve bilmeyenler olarak iki kategoriye ayrılmıştır. Katılımcıların 8 'i belediye tarafından yaşlılara sunulan hizmetleri bildiğini; 7'si bilmediğini belirtmiştir.

Giresun Belediyesinin yaşlılar için sunduğu hizmetlerden haberdar olan katılımcilar:

- "Belediyenin sağladığı bazı olanaklar var. Yaşlılar için Gazi caddesinde yaşlıları ücretsiz taşıma hizmeti var mesela. Yürüyemeyen, eşyasın taşımakta güçlük çeken yaşlları belirli bir yere kadar götürüuyor." (K1) 
- "Otobüsler ücretsiz. Başka da bir hizmetini bilmiyorum. Otobüs de kullanmıyorum zaten." (K10) şeklinde ifade etmişlerdir.

Belediyenin hizmetlerinden haberi olmayan bir katılımcı ise bu durumu aşağıdaki şekilde ifade etmiş̧ir:

- "Bazı yerlerde yaşlılarm evlerine temizlik için elemanlar gönderiliyormuş. Büyük şehirlerde yaşayan akrabalarmdan duydum. Bizim buralarda böyle bir uygulama yok. Varsa da benim haberim olmadı." (K3)

Yerel yönetimlerin yaşlıların yaşam kalitelerini artırmaya yönelik hizmetleri bulunmaktadır. Nitekim bu hizmetler Türkiye'de Yaşlanma ve Ulusal Eylem Planı Uygulama Programı́nda (2013) gıda ve yakacak yardımı, ev temizliği, evlere yemek dağıtımı, ambulansla evden sağlık hizmetleri olarak belirtilmiştir. Giresun Belediyesi'nin bünyesinde ise Evde Bakım ve Sağlık Hizmetleri Birimi bulunmaktadır. Birimin sosyo-ekonomik açıdan ihtiyacı olan yaşlı ve engelli bireylerin talepleri doğrultusunda bireylere ev temizliği ve kişisel bakım hizmetleri vermenin yanı sıra ayni yardım da yaptığı; ayrıca yaşlı ve engelli taşıma hizmetinin de olduğu bilinmekle birlikte (Giresun Belediyesi, 2020); çalışmaya dahil edilen 7 katılımcının verilen hizmetlere yönelik bilgisinin olmadığı belirlenmiştir. Bu noktada yerel yönetimlere büyük görevler düşmektedir. Sunulan hizmetlerin yaşlılara duyurulması, yaşlılardan talep ve başvuru almaksızın hizmet götürülmesinin gerektiği düşünülmektedir. Doğan- Sezer ve Artan (2019) tarafından İstanbul'da bulunan 39 ilçe belediyesinin yaşlılara yönelik sundukları hizmetlerin belirlenmesi amacıyla yaşlı hizmetlerinden sorumlu müdürlerle yapılan çalışmada; verilen hizmetlerin yetersiz olduğuna vurgu yapılarak çoğu belediyenin yaşlılara yönelik hizmetlerinin olduğu (yaşlı hizmet merkezinin ve huzurevinin bulunması, evde bakım hizmetlerinin verilmesi vb.) sorumlu müdürler tarafından ifade edilirken; yaşlılara yönelik hiçbir hizmetin olmadığı belediyelerinde $(n=7)$ olduğu belirlenmiştir. Özdemir' in (2017) 65-74 yaş aralığında olan 164 yaşlı bireyin Ankara'da Etimesgut Belediyesi tarafından yaşllara yönelik verilen hizmetleri nasıl algıladığına ilişkin yürüttüğü çalışmasında; belediye tarafından yaşlılara yönelik olarak huzurevi, evde bakım hizmeti ve emekli konakları aracılığıyla hizmetlerin verildiği, yaşlıların da verilen bu hizmetlerden genel olarak memnun oldukları sonucuna varılmıştır. 


\section{Katılımcılarnn Kurum Bakım Hizmeti Almaya Yönelik Düşünceleri ile Geliri Yeterli Bulma Durumuna İlişkin Bilgileri}

Katilımcllara kurumsal bakım hizmeti almak isteyip istemedikleri sorulduğunda ise yine yaşl1ların tümünün "kalan ömrünü evinde geçirmek istedikleri" belirlenmiştir. İlgili alan yazın incelendiğinde; Türk toplumunda yaşlıların çocuklarının yanında ya da kendi evlerinde yaşlanmayı tercih ettiklerini, zorunlu kalmadıkça kurumsal bakımı almak istemediklerini belirten çok sayıda çalışmaya rastlanılmıştır (Akgül, 2018; Çiçek, Şahin ve Erkal, 2020; Kalınkara ve Arpacı, 2013; Özmete, 2017). Özmete'nin (2017) çalışmasında da yaşlılar çocuklarının onlara bakmasını istedikleri, bu kurumları son çare olarak tercih edecekleri belirtilmiştir. Yüksek gelir grubunda olan yaşlıların çocuklarına yük olmayı istemeyerek kendi yaşıtlarında ki bireylerle kalmayı istemeleri; alt gelir grubunda olan yaşlıların ise bakım alacağ kişilerin olmayacağı hatta çocuklarının birlikte yaşamayı istemeyeceği düşüncesine sahip olmaları nedeniyle kurum bakımı almayı tercih ettikleri belirlenmiştir (Aközer, vd. 2011, s.130). Ancak ülkemizde yerinde yaşlanmayı tercih eden tüm yaşlıları kapsayan etkin bir şekilde işlerliği olan evde bakım sistemi halen bulunmamaktadir.

Son soru olarak yaşlılara "ülkemiz şartlarını düşündügünüzde gelirinizi yeterli buluyor musunuz?" sorusu yöneltilmiş olup "gelirimi yeterli bulmuyorum. Emekli maaşımız artık hiçbir şeye yetmeyecek duruma geldi" diyenler katılımcıların tamamını oluşturmaktadır. TÜİK'in yapmış olduğu 2018 yılı Hanehalkı Tüketim Harcaması araştırmasında hanehalkı büyüklüğü ve kompozisyonu dikkate alınarak hesaplanan eşdeğer fert başına aylık ortalama tüketim harcaması 2017 yılında 1854 TL, 2018 yllında 2.181 TL olarak tahmin edilmiştir (TÜİK, 2019). Ülkemizde emekli maaş miktarları, çalışmaya katılan yaşlıların söylemleri ve TÜİK'in çalışmasının sonuçlarına göre yaşlıların gelirlerinin yetersiz olduğu açıkça görülmektedir. Aile, Çalışma ve Sosyal Hizmetler Bakanlığı'nın 2019 yılında yayınladığı Engelli ve Yaşlı İstatistik Bülteni verilerine göre de Türkiye'de 65 yaş ve üzeri yaşlıların \%15,5'inin yoksul olduğu belirlenmiştir. TÜİK'in 2019 İstatistiklerle Yaşlılar çalışmasına göre Türkiye nüfusunun (82.003.882 kişi) \%9,1'inin (7.550.727 kişi) 65 yaş ve üzeri olduğu düşünüldüğünde; yoksul olduğu bilinen yaşlı sayısı (1.170.362 kişi) oldukça yüksektir. 


\section{Sonuç ve Öneriler}

Giresun ili merkezinde yaşayan 65 yaşın üzerindeki 15 yaşlı bireyin katılımıyla yaşlı bireylerin aktif yaşlanma tecrübelerini belirlemek amaciyla 24 Ocak - 4 Şubat 2020 tarihleri arasında yüz yüze görüşmeler gerçekleştirilmiştir. Nitel araştırma yöntemi ile yürütülen çalışmada veri toplama araçlarından elde edilen verilerin dökümü yapılarak analizleri gerçekleştirilmiştir. Yaşlıların aileleri ve toplum için yaşam kalitesi ve toplumsal iyiliğe katkıları açısından önemli kaynak olduğu; deneyimlerinin ve bilgeliklerinin genç nesiller ve yetişkinlere aktarımının yararlı olacağı düşünülmektedir (Öz, 2002). Yaşlılık/yaş alma tecrübe/ bilgi birikiminin insan yaşamında üst seviyelere ulaştı̆̆1 evredir (Dönümcü, 2006). Bu süreç ekonomik anlamda gerilemeye sebep olsa da bilgi ve tecrübe birikiminin en üst düzeyde olduğu çağdır. Yapılan bu nitel çalışma ile Giresun ilinde yaşayan 65 ve üzeri yaşlı bireylerin aktif yaşlanmaya ilişkin tecrübelerine yönelik olarak ön bilgilerin belirlenmesi ve çerçevenin çizilmesi hedeflenmiştir. Bu açıdan düşünüldügünde, konu ile ilgili araştırma yapacak bilim insanlarına yol göstermesi amaçlanmiştır.

Araştırmada yaşlılar arasında tansiyon hastalı̆̆ı olduğunu, sigara kullanmadığını belirtenler ilk sırada yer almaktadır. Çalışmada yaşlılar arasında komşuluk ilişkilerini "kardeşlik" olarak belirtenlerin oranının yüksek olması geleneksel kültürümüzde de komşuya verilen önemden kaynaklanabilir. Bu ilişkilerin iyi olması yaşlıların kendilerini yalnız hissetmemelerini sağlayarak aktif yaşlanma sürecine olumlu katkı sağladığı düşünülmektedir.

Yaşlıların torunları ile ilişkilerinde düzenli olarak görüştügünü belirtenlerin çoğunlukta olması memnuniyet vericidir. Yaşlıların deneyimlerinden ve bilgeliklerinden genç neslin de faydalanabilecekleri ortamların oluşturularak bu ilişkilerin daha da güçlendirilmesi için ailelere de sorumluklar düşmektedir. Yaşlı bireyin aile bireyleri ile ilişkileri iyi olduğu zaman bu etki torunlara da olumlu yansıyacaktır. Aile ilişkilerinin olumlu yönde etkilenmesini sağlayacak televizyon programlarının, eğitici programların, kamu spotlarının planlanması yararlı olacaktır.

Yaşlı bireylerin boş zaman faaliyetleri incelendiğinde; "el işi” yaptı̆̆ını belirtenler çoğunluktadır. Çalışmaya katılan yaşlılar arasında kadınların fazla sayıda olmasının bu sonucu etkilediği düşünülebilir. Aktif yaşlanma için, bi- 
reylerin aktif bir hayat sürmesine katkı sağlayan boş zaman aktivitelerine katılım teşvik edilmelidir. Yaşlıların boş zamanlarını değerlendirebilecekleri televizyon programlarının yapılması, fiziksel, sanatsal ve kültürel faaliyetlere yer verilmesi gerekir. Bu bağlamda yerel yönetimler tarafından yaşlıların keyif alarak boş zamanlarını değerlendirebilecekleri fiziksel aktiviteler, sanatsal ve kültürel faaliyetlere (okuma, dinlenme, resim yapma, spor yapma, sinemaya ve tiyatroya gitme gibi) katılım gösterebilecekleri merkezlerin kurulması önerilebilir. Sivil Toplum Kuruluşlarının da bu bağlamda etkinlikler düzenlemesi, yaşlılara yönelik projeler hazırlayarak bunları uygulaması önemlidir.

Çalışmada yaşlılar arasında akıllı telefon kullananlar önde gelmektedir. Yaşlı bireylerin teknoloji aracılığıyla yakınları ile iletişim kurması önemlidir. Ancak çalışmaya katılan yaşlılar arasında akıllı telefon ya da bilgisayar kullanmayanların da bulunması dikkat çekicidir. Bu konuda yaşlıların teknolojik araçları kullanmayışının nedeni belirlenerek, destek programlarının hazırlanması ve teknoloji kullanımlarının artırılmasına yönelik çalışmaların yapılması önerilebilir. Ayrıca yaşlıların teknoloji kullanımının önündeki bireysel engellerden olan teknolojik yeniliklere olan tutuma ilişkin (teknolojinin tehlikeli, pahalı, karmaşık, şaşırtıcı, öğrenmesi güç olduğuna ilişkin algı) ve yetersiz eğitim ve destek hizmetlerininin artırılması (eğitim almaya ilişkin mali engeller ve eğitim olanaklarının yoksunluğu, öğrenme süresince yeterli desteği ve eğitimcileri sağlamaya yönelik kaliteli eğitim olanaklarının yoksunluğu vb.) (Blaschke, Freddolino ve Mullen 2009) konularında teknoloji kullantmıyla yaşam kalitelerinin yükseltilmesini sağlamak açısından yaşlıların bilgi ve bilinç düzeylerinin artıılması amacıyla yaşlılara yönelik eğitimler düzenlenebilir.

Çalışmaya katılan bireyler arasında Giresun ilinde yerel yönetimin yaşl1lara yönelik hizmeti olduğunu bilmeyenler de bulunmaktadır. Sunulan hizmetlerin yaşlılara duyurulması, yaşlılardan talep ve başvuru almaksızın hizmet götürülmesinin gerektiği düşünülmektedir. Yerel yönetimlerin yaşlıların yaşam kalitesini artırmaya yönelik hizmetleri çok önemlidir ve ülkemizde de bu hizmetleri (ev temizliği, evde bakım ve sağlık hizmeti, taşıma hizmeti vb.) veren belediyeler bulunmaktadır. Türkiye genelinde tüm il ve ilçe belediyelerinin yaşlılara yönelik hizmetlerin verilmesi ve mevcut hizmetlerin ise yaygınlaştırılması sağlanabilir. 
Genel olarak baktığımızda ülkemizde yaşlılıkta aktif yaşlanma bilincinin yaygınlaştırılması önemli bir konudur. Yaşlılık, yaşlıya bakım sağlamanın ötesinde, yaşlının toplumla bütünleşmesi, kaybolan statü ve rollerin yeniden kazanımı, işlevlerin artırılması, boş zamanlarının etkili değerlendirilmesi, gelirlerinin artırılması gibi boyutlarıyla bir bütün olarak değerlendirilmeli ve bu konuda gerekli politikalar üretilmelidir. 


\title{
EXTENDED ABSTRACT
}

\section{Active Aging Experiences of the Elderly: A Qualitative Study}

\author{
* \\ Birgül Çiçek - Hande Şahin- Sibel Erkal \\ Hacettepe University, Kırıkale University, Kırıkkale, Turkey
}

This study was planned to determine the experiences of 15 individuals aged 65 and above living in Giresun regarding active aging. A semi-structured interview form was prepared as a data collection tool. In the interview form, there are questions regarding the sociodemographic characteristics of the elderly (sex, age, the status of having social security, living situation, the number of children, the number of grandchildren), health status (health problem, smoking status, and the number of daily meals), and questions about relationships with neighbours and grandchildren, leisure activities, use of technology, use of local government services for the elderly, thoughts about receiving institutional care services and finding income sufficient to reveal daily living practices. The data were collected using the "individual in-depth interview" method. Descriptive analysis and content analysis methods, among the qualitative data analyses, were used in the analysis of the data. The answers given by the participants to the questions in the interview form were written out by the researchers in their plain form without adding any comments for validity. Elderly male individuals were expressed as M1, M2, M3, M4 and M5, while elderly female individuals were expressed as W1...........W10. The opinions obtained were coded separately, classified by grouping common statements, and categories were created. The created categories were presented to the opinions of the experts in the related field, and they were reviewed and finalized. Tables were created for the general information about the sociodemographic and health status of the elderly and each question asked. At the same time, the answers of some participants to each question were given in the form of direct quotations. In the study carried out with the qualitative research method, the data obtained using the data collection tools were itemized and analysed. The aim of this qualitative study was to 
determine preliminary information and draw a framework related to the experiences of individuals aged 65 and above living in Giresun province with regard to active aging. When considered from this point of view, the aim was to guide scientists who will conduct research on the subject.

The participants consisted of 10 women and 5 men. The mean age of the elderly individuals was $70.1 \pm 2.4$. Of the elderly individuals, 7 stated their income level as "medium," 5 as "low," and 3 as "high." Among the elderly individuals, those who retired from the Pension Fund ( $n=10)$, those who had 2 children $(n=9)$, those who had 2 grandchildren $(n=8)$ and those who lived with their children $(n=6)$ came to the forefront. While 10 of the elderly individuals stated that they had blood pressure disease, and 13 of them stated that they did not smoke, those who ate 3 meals a day constituted the majority $(n=10)$.

Approximately half of the elderly individuals $(n=8)$ defined their neighbourhood relations as "fraternity," 4 as "solidarity," and 3 as "unity and togetherness." While 12 of the individuals stated that they had a continuous and regular relationship with their grandchildren, they frequently called each other and met, 3 individuals stated that the relationship between them was broken. Considering the leisure activities, 8 of the elderly individuals stated that they did handicrafts, 3 walked, 2 worshipped, and 2 watched TV. When technology use was examined, 8 of the participants stated that they used smartphones and 2 used computers, while 5 were not good with technology and did not use a smartphone or computer.

The elderly individuals who participated in the study were asked the questions of "Does the local government in your province have home care services for the elderly?" and "Do you benefit from these services?", and 8 of the elderly individuals stated that "The local government has home care services for the elderly. When the participants were asked whether they would like to receive institutional care, it was again determined that all of the elderly individuals "wanted to spend their remaining life at home." All of the participants answered the question of "Do you think your income is sufficient when you consider the conditions of our country?" in the form of "I do not find my income sufficient. Our retirement salary is now not enough for anything."

When evaluated in general, it is an important issue to expand the awareness of active aging in Turkey. Old age, beyond providing care for the elderly, should be evaluated as a whole with its dimensions such as integration of the elderly with society, recovery of the lost statuses and roles, increasing the 
functions, effective utilization of leisure time and increasing the income, and necessary policies should be produced in this regard.

\section{Kaynakça / References}

Akgül, H. (2018). Aksu ilçesinde (Isparta) karsal nüfusun yaşlanması ve yaşl nüfusun sorunları. Yüksek Lisans Tezi. Süleyman Demirel Üniversitesi Sosyal Bilimler Enstitüsü, Isparta.

Aközer, M., Baran, A.H., Kalaycıoğlu, S., Özler, G., Nuhrat R.C. vd. (2011). Türkiye'de yaşlllk dönemine ilişkin beklentiler. Ankara: T.C. Aile ve Sosyal Politikalar Bakanlığı Aile ve Toplum Hizmetleri Genel Müdürlüğü Yayınları.

Akturan, U. ve Esen, A. (2008). Fenomenoloji. T. Baş ve U. Akturan (Ed.), Nitel araştırma yöntemleri içinde (s. 83-98). Ankara: Seçkin Yayıncıllk.

Allison, M. T. ve Smith, S. (1990). Leisure and quality of life: Issues facing racial and ethnic minority elderly. Therapeutic Recreation Journal, 24, 50-63.

Altuntaş, O. ve Kayıhan, H. (2012). Ev düzenlemelerinin yaşlllarda günlük yaşam aktivtiviteleri, mobilite ve denge üzerine olan etkisi. Akademik Geriatri Dergisi, 4,78-88.

Arpacı, F. (2015). Yaşlı bireylerin yaşam kalitesi açısından günlük yaşam aktivitelerini yapabilme durumunun incelenmesi. Yaşl Sorunlan Araştırma Dergisi, 1, 46-53.

Aslan, D. (2020, 10 Nisan). Aktif yaşlanma kavramı. http://www.turkgeriatri.org/halksagligi?id=12 adesinden erisilmiștir.

Aydın, İ. ve Tütüncü, Ö. (2017). Yaşlllık ve rekreasyon. Anatolia: Turizm Araştırmalan Dergisi, 28(2), 315-321.

Baran-Görgün, A., Kurt-Koçak, Ş. ve Tekeli-Serdar, E. (2017). Yaşllların dijital teknolojileri kullanım düzeyleri üzerine bir araş九ırma, İletişim Kuram ve Araştrrma Dergisi, 1(45), 3-24.

Bayrak, F. (2018). Yaşlllk olgusuna sosyolojik bir yaklaşım. Yüksek Lisans Tezi, Frrat Üniversitesi Sosyal Bilimler Enstitüsü, Elâzı̆̆.

Blaschke, C.M., Freddolino, P.P., ve Mullen, E. E. (2009). Ageing and technology: A review of the research literature. British Journal of Social Work, 39, 641-656.

Caldwell, L., Smith, E. ve Weissenger, E. (1992). The relationship of leisure activities and perceived health of college students. Society and Leisure, 15, 545-556.

Çetin, A. (2002). Yaşam kalitesi ve rehabilitasyon. Y. Gökçe Kutsal (Ed.), Geriatri 2002 kitabı içinde (s. 218-221). İstanbul: Turgut Yayıncllk.

Çiçek, B., Şahin, H. ve Erkal, S. (2020). Determination of the opinions of individuals aged 65 and over on aging in place: the case of Ankara. Educational Gerontology, 46(4), 182-194. 
Çubuk, Ç. (2019). 60 yaş üstü bireylerin katlldkklar yaşam doyumu, sağhlk algısı ve boş zaman aktivite tercihlerinin incelenmesi. Yüksek Lisans Tezi, Mersin Üniversitesi Eğitim Bilimleri Enstitüsü, Mersin.

Danış, M. Z. (2008). Toplum temelli bakım anlayışı ve sosyal hizmetler: Türkiye örneğinde bir bakım model önerisi. Türk Geriatri Dergisi, 11(2), 94-105.

Danış, M.Z. (2020, 10 Nisan). Yaşlllık, yoksulluk ve yalnızlık. http://www.gebam.hacettepe.edu.tr/sosyal boyut/yaslilik yoksuluk yanlizlik.pdf adresinden erişilmiştir.

Demirbaş, S. (2018). Yaşllıkta sosyal ilişkiler. A. Canatan ve E. Özmete (Ed.). Temel Gerontoloji kitabı içinde. Ankara: Hedef CS Basım Yayın.

Doğan-Sezer, A. ve Artan, T. (2019). İstanbul ilçe belediyelerinde görev yapan müdürülerin yaşlı farkındalığı üzerine karma desenli bir araşırma. Sosyal Çalışma Dergisi, 3(2), 120-146.

Dönümcü, Ş. (2006). Yaşlı ve sosyal hizmetler. Türkiye Fiziksel Tip ve Rehabilitasyon Dergisi, 52(Özel Ek A), 42-46.

Dupuis, S. ve Smale, B. (1995). An examination of the relationship between psychological wellbeing and depression and leisure activity participation among older adults. Society and Leisure, 18, 67-92.

Durak, M. (2013). Yaşlılık döneminde psiko-sosyal ve bilişsel gelişim. H. Bacanlı ve Ş. Terzi (Ed.), Yetişkinlik ve yaşlllık gelişimi ve psikolojisi kitabı içinde. (s.275-310). Ankara: Açllım Kitap.

Ersoy, A. (2016). Fenomenoloji. A. Saban ve A. Ersoy (Ed.), Eğitimde nitel araştırma desenleri kitabı içinde. (s. 81-137). Ankara: Anı.

Esendemir, Ş. (2016). Türkiye'de yerinde yaşlanma ve mekân gerontolojisinin temel parametreleri. Sosyoloji Dergisi, 36(2), 13-31.

Giresun Belediyesi (2020, 8 Nisan). Evde bakım ve sağlı hizmetleri her zaman vatandaşım yannda. https://giresun.bel.tr/evde-bakim-ve-saglik-hizmetleri-her-zamanvatandasin-yaninda/adresinden erişilmiştir.

Gökçe-Kutsal, Y. (2011). Yaşlanan dünyanın yaşlanan insanları. 08.04.2020 tarihinde http://www.geriatri.org.tr/SempozyumKitap2011/3.pdf adresinden erişiilmiştir.

Gönen, E. ve Özmete, E. (2005). Yaşlılar için evin anlamı. Ş. Ergin (Ed.), III. Ulusal yaşlllk kongresi bildiriler kitabı içinde. (s.272-278). İzmir: YASAD Yayınları.

İçli, G. (2008). Yaşlılar ve yetişkin çocuklar. Yaşlı Sorunlan Araştırma Dergisi,1, 29-38.

Kalaycıŏlu, S. (2012, Mart). Kuşaklararası dayanışma ve aktif yaşlanma. A. Metin ve ark. (Ed.). Kuşaklararası dayamışma ve aktif yaşlanma sempozyumu bildiriler kitabı içinde (s.51-58). Ankara, Türkiye: Grafer Tasarım Baskı. 
Kalınkara, V. ve Arpacı, F. (2013, Mayıs). Yerinde yaşlanma. V. Kalınkara (Ed.). VII. Ulusal Yaşlllkk Kongresi bildiriler kitabı içinde (s.54-60). 23-25 Mayıs 2013 Karabük.

Kılavuz, M. A. (2005). Batı kültüründe yaşlanma dönemi yalnızlık duygusunu azaltma ve arkadaş ilişkilerini geliştirme açısından dini etkinliklerin önemi. T.C. Uludağ Üniversitesillâhiyat Fakültesi Dergisi, 14, 25-39.

Kuyken, W., Orley, J., Power, M., Herrman, H., Schofield, H., Murphy, B., Metelko, Z., Szabo, S., Pibernikokanovic, M., Quemada, N., Caria, A., Rajkumar, S., Kumar, S., Saxena, S., Baron, D., Amir, M., Tazaki, M., Noji, A., Vanheck, G., ..., Vandam, F. (1995). The World Health Organization Quality of Live assessment (WHOQOL): Position paper from the the World Health organization. Social Science \& Medicine, 41(10), 1403-1409.

Merriam, S. B. (2013). Nitel araştırma desen ve uygulama için bir rehber (S. Turan, Çev.). Ankara: Nobel.

Neuman, W.L. (2003). Social research methods: qualitative and quantitative approaches. Allyn and Bacon: Boston, United States.

Oktik, N. ve Bozyer, Ü. (2004). Huzurevinde yaşam ve yaşam kalitesi: Muğla örneği. Muğla: Mugla Üniversitesi Yayınları.

Öz, F. (2002). Yaşamin son evresi: Yaşllık psikososyal açıdan gözden geçirme. Kriz Dergisi, 10(2), 17-28.

Özdemir, H. (2017). Yaşlların belediyelerce verilen hizmetlere bakış açısl: Etimesgut Belediyesi örneği. Yüksek Lisans Tezi, Başkent Üniversitesi Sosyal Bilimler Enstitüsü, Ankara.

Özkan, M. (2017). Yaşllarda mekan aidiyeti: Yaşlllk ve mekan ilişsisine sosyolojik bakış. Yüksek Lisans Tezi. Selçuk Üniversitesi Sosyal Bilimler Enstitüsü, Konya.

Özkan, Y. ve Purutçuoğlu, E. (2010). Yaşlllıkta teknolojik yeniliklerin kabulünü etkileyen sosyalizasyon süreci. Aile ve Toplum, 6(23), 37-46.

Özkul, M., Kalaycı, I. ve Atasoy, M. (2019). Yaşlıların toplumsal ilişki kurma biçimleri: Sorunlar ve imkânlar. Akademik Sosyal Araşttrmalar Dergisi, 37, 77-97.

Özmete, E. (2014). Kuşaklararası dayanışma. E. Ertekin (Ed.) VI. Aile Şurası Komisyon Raporlan ve Bildiriler kitabı içinde (s.211-237). Ankara: T.C. Aile ve Sosyal Politikalar Bakanlı̆ğ.

Özmete, E. (2017). Türkiye'de kuşaklararası dayamısmanın değerlendirilmesi. Ankara: Ankara Üniversitesi Basımevi.

Özyurt-Cengiz, B., Eser, E., Çoban, G., Akdemir S. N., Karaca, İ. Ve Karakoç, Ö. (2007). Manisa Muradiye Bölgesindeki yaşllların yaşam kalitesini etkileyen faktörlerin değerlendirilmesi. Türk Geriatri Dergisi, 10(3), 117-123. 
Patton, M.Q. (2014). Nitel araştırma ve değerlendirme yöntemleri. (M. Bütün ve S.B. Demir Çev.). Ankara: Pegem Akademi.

Paul, G. ve Stegbauer, C. (2005). Is the digital divide between young and elderly people increasing?. First Monday, 10(10). https://doi.org/10.5210/fm.v10i10.1286

Raymore, L. and Scott, D. (1998). The characteristics and activities of older adult visitors to a metropolitan park district. Journal of Park and Recreation Administration, 16(4), 1-21.

Sarıoğlu, H. ve Ertuğrul, İ. (2001). Yaşlıların el sanatları faaliyetleri üzerine bir araştırma. V. Kalınkara (Ed.), I. Ulusal Yaşlılık Kongresi Kitabı içinde (s.117-194). Ankara: Yaşlı Sorunları Araştırma Derneği Yayını.

Stav, W. B., Hallenen, T., Lane, J. ve Arbesman, M. (2012). Systematic review of occupational engagement and health outcomes among community-dwelling older adults. Am J Occup Ther, 66(3), 301-310.

Sungur, F. ve Hazer, O. (2018). Analysis of the acceptance of communication technologies by acceptance model of the elderly: Example of Adana province, International Journal of Eurasia Social Sciences, 9(31), 238-275.

Şener, A., Öztop, H., Güven, S. ve Doğan, N. (2007). Aile, yakın akraba ve arkadaş ilişkileri: yaşlıların yaşam doyumu üzerindeki farklı etkileri. V.Kalınkara veG. Akın (Ed.). 4. Ulusal yaşlılık Kongresi kitabı içinde (s.151-167). Ankara: Yaşlı Sorunları Araştırma Derneği.

Şentürk, M. ve Ceylan, H. (2015). İstanbul'da yaşlanmak. İstanbul: Açılım Kitap.

Şentürk, M. ve Kurtkapan, H. (2017). Yaşlılığın mekânsallaşması: Kadıköy Moda'daki bir apartman üzerine nitel bir çalışma. Senex: Yaşlılık Çalışmalan Dergisi, 1(1), 419.

T.C. Aile, Çalışma ve Sosyal Hizmetler Bakanlığı [AÇSHB]. (2013). Türkiye'de yaşlanma ve ulusal eylem planı uygulama programı. Engelli ve Yaşlı Hizmetleri Genel Müdürlüğ̈̈, Ankara.

T.C. Aile, Çalışma ve Sosyal Hizmetler Bakanlığı [AÇSHB]. (2018). Türkiye'de yaşllara yönelik hizmetler ile kurumsal yaşlı bakımı ve illerin durumu. Ertem Basım: Ankara.

T.C. Aile, Çalışma ve Sosyal Hizmetler Bakanlığı [AÇSHB]. (2019). Engelli ve yaşh istatistik bülteni. Engelli ve Yaşlı Hizmetleri Genel Müdürlüğü, Ankara.

Tufan, İ. ve Yazıcı, S. (2009). Yaşlılıkta kuşaklararası ilişkiler. Toplum ve Sosyal Hizmet, 20(1), 47-52.

Türkiye İstatistik Kurumu [TÜIK]. (2018). Nüfus projeksiyonları: 2018-2080. Haber Bülteni, Sayı: 30567. http://www.tuik.gov.tr/PreHaberBultenleri.do?id=30567 adresinden erişildi. 
Türkiye İstatistik Kurumu [TÜİK]. (2019). Hane halk tüketim harcamasl: 2018. Haber Bülteni, Sayl: 30584. http://www.tuik.gov.tr/PreHaberBultenleri.do?id=30584 adresinden erişilmiştir.

Türkiye İstatistik Kurumu [TÜIK]. (2019a). Hayat tablolarl: 2016-2018. Haber Bülteni, Sayl: 30712. http://www.tuik.gov.tr/PreHaberBultenleri.do?id=30712 adresinden erişilmiştir.

Türkiye İstatistik Kurumu [TÜIK]. (2020). İstatistiklerle yaşllar: 2019. http://www.tuik.gov.tr/PreHaberBultenleri.do?id=33712 adresinden erişilmiştir.

Wang, L., Rau, P-L. P. ve Salvendy, G. (2011). Older adults' acceptance of information technology, Educational Gerontology, 37(12), 1081-1099.

West, G. E., Delisle, M.A., Simard, C. ve Drouin, D. (1996). Leisure activities and service knowledge and use among rural elderly. Journal of Aging and Health, 8(2), 254 279 .

World Health Organization [WHO]. (2002). Active ageing: A policy framework. https://apps.who.int/iris/bitstream/handle/10665/67215/WHO NMH_NPH 02.8.pdf?sequence $=1$ \&isAllowed $=y$ adresinden erişilmiştir.

Yüksel, M. Y., Dinçer, F., Büyükköse, H. T. ve Lale, Z. H. (2014). Yaşllların boş zaman değerlendirmesi üzerine bir inceleme. Ĕgitim ve Öğretim Araştırmalan Dergisi, $3(1), 107-114$.

Zimmer, Z. ve Chappell, N.L. (1999). Receptivity to new technology among older adults. Disability and Rehabilitation, 21(5/6), 222-230.

2022 sayılı 65 Yaşını Doldurmuş Muhtaç, Güçsüz ve Kimsesiz Türk Vatandaşlarına Aylık Bağlanması Hakkında Kanun (Temmuz 10, 1976). Resmi Gazete. Sayı: 15642 10.04.2020 tarihinde https://www.mevzuat.gov.tr/MevzuatMetin/1.5.2022.pdf adresinden erişilmiştir.

\section{Kaynakça Bilgisi / Citation Information}

Çiçek, B., Şahin, H. ve Erkal, S. (2021). Yaşlıların aktif yaşlanma tecrübeleri: Nitel bir çalışma. OPUS-Uluslararası Toplum Araştırmaları Dergisi, 17(33), 369-397. DOI: 10.26466/opus.773745 